DOI https://doi.org/10.30525/978-9934-588-92-1-77

\title{
ДО ПИТАННЯ ПРЕДМЕТУ КРИМІНАЛЬНОГО ПРАВОПОРУШЕННЯ СТАТТІ 364-1 КРИМІНАЛЬНОГО КОДЕКСУ УКРАЇНИ
}

\author{
Мельниченко В. С. \\ аспірант кафедри кримінального права та правосуддя \\ Запорізького національного університету \\ м. Запоріжжя, Україна
}

Статтею 364-1 Кримінального кодексу України (далі ККУ)[1] передбачена кримінальна відповідальність за вчинення такого кримінального правопорушення (злочину), як зловживання повноваженнями службовою особою юридичної особи приватного права незалежно від організаційно-правової форми.

Основними елементами кримінального правопорушення загальновизнано є суб'єкт, суб'єктивна сторона, об'єкт, об'єктивна сторона. Однак є і факультативні ознаки кримінального правопорушення, на які також слід звертати увагу. Однією 3 таких факультативних ознак $\epsilon$ предмет кримінального правопорушення. В цій роботі ми будемо 3'ясовувати, що може бути предметом вчинення кримінального правопорушення статті 364-1 ККУ. Але для початку 3'ясуємо визначення, що $\epsilon$ предметом кримінального правопорушення. Укладачі підручника 3 загальної частини кримінального права України за загальною редакцією В.Я. Тація, В.І. Тютюгіна, В.І. Борисова наводять наступне визначення предмета кримінального правопорушення: «Предметом кримінального правопорушення $\epsilon$ будь-які речі матеріального світу, з певними властивостями яких кримінальний закон пов'язує наявність у діях особи ознак конкретного складу кримінального правопорушення» [2, с. 128]. В цій роботі ми не будемо освітлювати інші наукові позиції та вести щодо них дискусії, оскільки у нас інша мета роботи та обмежений обсяг. Дане питання буде більш детально досліджено в дисертаційному дослідженні.

Слід зазначити, що предмет кримінального правопорушення - це така ознака складу кримінального правопорушення, яка називається безпосередньо в самому законі про кримінальну відповідальність. Тоді, в такому випадку, предмет виступає як обов'язкова ознака складу кримінального правопорушення, кримінальне правопорушення $\epsilon$ предметним i для правильної правової кваліфікації має бути 
встановлений конкретний предмет кримінального правопорушення. Однак, якщо законодавець не дає безпосередню вказівку на предмет в кримінальному законі, то предмет не може бути ознакою складу кримінального правопорушення.

Отже, що ж може бути предметом кримінального правопорушення досліджуваного нами кримінального правопорушення? Перед тим, як ми почнемо давати відповідь на це запитання, звернемося до диспозиції статті 364-1 ККУ. Відповідно до ч. 1 ст. 364-1 ККУ під зловживанням повноваженнями розуміється умисне, з метою одержання неправомірної вигоди для себе чи інших осіб використання всупереч інтересам юридичної особи приватного права незалежно від організаційно правової форми службовою особою такої юридичної особи своїх повноважень. Кримінальне правопорушення статті 364-1 ККУ $\epsilon$ кримінальним правопорушенням у сфері службової діяльності. Автори коментованого ККУ вважають, що предметом деяких кримінальних правопорушень, передбачених розділом XVII ККУ, є неправомірна вигода. Також зазначено, що у статтях 364, 364-1, 365-2 і 369-3 неправомірна вигода $\epsilon$ метою кримінального правопорушення [3, с. 1143]. Однак, якщо така неправомірна вигода обертається винним на свою користь внаслідок вчинення протиправних дій, то вважаю, що неправомірна вигода може бути також предметом досліджуваного нами кримінального правопорушення. 3 цього приводу доцільно буде звернутися до вітчизняної судової практики: ОСОБА 1, яка обіймала посада генерального директора ТОВ «БУД - ВІК», була визнана винною У вчиненні кримінального правопорушення, передбаченого ч. 2 ст. 364-1 ККУ на підставі вироку Біловодського районного суду Луганської області від 22 березня 2018 року у справі № 408/1005/18-к [4]. Проаналізувавши згаданий вирок, можемо прийти до висновку, що ОСОБА 1, зловживаючи своїми повноваженнями, отримала неправомірну вигоду в розмірі 399265 грн. 84 коп. Вважаємо за доцільне 3'ясувати поняття «неправомірна вигода». Відповідно до примітки до статті 364-1 ККУ у статтях 364, 364-1, 365-2, 368, 368-3, 368-4, 369, 369-2 та 370 цього Кодексу під неправомірною вигодою слід розуміти грошові кошти або інше майно, переваги, пільги, послуги, нематеріальні активи, будь - які інші вигоди нематеріального чи негрошового характеру, які пропонують, обіцяють, надають або одержують без законних на те підстав. В нашому випадку мало місце незаконне одержання грошових коштів, оскільки вони були отримані внаслідок внесення недостовірних даних, а також подальше затвердження актів приймання виконаних робіт відповідно до договору № 157 на здійснення робіт по об'єкту «Реконструкція каналізаційного колектору, мережі та каналізаційної 
насосної станції смт. Петрівка Станично -Луганського району Луганської області», оскільки по вказаному об'єкту роботи були виконані не в повному обсязі. Отже, оскільки в даному випадку мало місце отримання неправомірної вигоди внаслідок зловживання повноваженнями, вважаємо, що неправомірна вигода в такому випадку є не лише метою вчинення протиправних дій, але $\epsilon$ також предметом кримінального правопорушення, оскільки тісно пов'язана 3 вчиненням даного кримінального правопорушення.

Предметом кримінального правопорушення також можуть бути підроблені документи. Знову звернемося до судової практики: Вироком Костянтинівського міськрайонного суду Донецької області від 16 травня 2016 року у справі № 233/2177/16-к ОСОБА 1 визнано винною у вчиненні кримінального правопорушення (злочину), передбаченого ч. 2 ст. 364-1, ч. 1 ст. 366 ККУ [5]. Коротко про обставини справи: ОСОБА 1 був призначений директором ТОВ «Укрпромтранс - сервіс». Між вказаним підприємством в особі директора ОСОБА 1 з Державним підприємством «Костянтинівський державний завод» було укладено договір підряду, згідно якого підрядник зобов'язується своїми силами, матеріалами та механізмами виконати роботи з будівництва депо та ремонту залізничних колій. В подальшому ОСОБА 1 , будучи службовою особою юридичної особи приватного права, достовірно знаючи, що фактично передбачені договором підряду роботи з будівництва депо та ремонту залізничних колій ДП «КДХЗ» не виконано, підписав офіційні документи - акти прийому виконаних будівельних робіт за даним договором, що містять недостовірні відомості в частині виконання ремонтних робіт вищевказаних залізничних колій та будівництва депо i тим самим видав зазначені документи, які в подальшому стали підставою для реєстрації кредиторських зобов'язань ДП «КДХЗ» перед ТОВ «УПТС» та надали можливість в подальшому стягувати 3 першого грошові кошти. Таким чином, судом було встановлено, що ОСОБА 1 вчинив усі дії, які вважав необхідними для доведення злочину до кінця, тобто неправомірне обрахування та облік кредиторських зобов'язань ДП «КДХЗ» перед ТОВ «УПТС» та стягнення відповідної суми коштів в судовому порядку.

Детальний аналіз зазначеного вироку свідчить, що кримінальне правопорушення, передбачене ч. 2 ст. 364-1 ККУ, було вчинено засудженим за допомогою підроблених документів. Таке підроблення судом кваліфіковано за ч. 1 ст. 366 ККУ. Відразу виникає питання, чому ж тоді підроблені документи будуть предметом кримінального правопорушення статті 364-1 ККУ у конкретному випадку. Пояснюємо. В даному випадку мала місце ідеальна сукупність кримінальних 314 
правопорушень. Ідеальна сукупність - ие ті випадки, коли особа однією $i$ тією самою дією вчиняє два чи більше кримінальних правопорушень, передбачених різними статтями КK [2, с. 294]. В нашому випадку ОСОБА 1 шляхом службового підроблення вчинив зловживання повноваженнями. Тобто, він підробив та використав офіційні документи для досягнення своєї злочинної мети. Таким чином, в даному випадку предметом кримінального правопорушення статті 364-1 ККУ слід вважати і неправомірну вигоду, яка була отримана внаслідок протиправних дій, і підроблені документи, оскільки вони були безпосередньо пов'язані з діями засудженого ОСОБА 1 щодо зловживання своїми повноваженнями.

На підставі вищевикладеного спробуємо сформулювати, що ж $\epsilon$ предметом кримінального правопорушення статті 364-1 ККУ.

Отже предметом кримінального правопорушення «Зловживання повноваженнями службовою особою юридичної особи приватного права незалежно від організачійно-правової форми $\epsilon$ mi речі матеріального світу, з приводу яких, стосовно яких, або за допомогою яких вчиняється це кримінальне правопорушення.

Слід зазначити, що це лише невелика частина нашого дослідження предмету кримінального правопорушення статті 364-1 ККУ. Більш детально ця проблематика буде розкрита у дисертаційному дослідженні та в інших наукових працях.

\section{Література:}

1. Кримінальний кодекс України: Закон України від 05.04.2001 p. № 2341-III.Дата оновлення: 16.10.2020. URL: https://zakon.rada.gov.ua/ laws/show/2341-14\#Техt (дата звернення: 26.10.2020)

2. Кримінальне право України: Загальна частина: підручник/ В.Я. Тацій, В.І.Тютюгін, В.І.Борисов та ін; за ред. В.Я. Тація, В.І. Тютюгіна, В.І. Борисова. 6-те вид., перероб. і допов. Харків.: «Право», 2020. 584 с.

3. Науково-практичний коментар Кримінального кодексу України / за ред. М.І. Мельника, М.І. Хавронюка. 11-те вид., переробл. та допов. К. : ВД «Дакор», 2019. 1384 с.

4. Вирок Біловодського районного суду Луганської області від 22.03.2018 року у справі № 408/1005/18-к. URL: http://www.reyestr.court.gov.ua/Review/72946815

5. Вирок Костянтинівського міськрайонного суду Донецької області від 16.05.2016 року у справі № 233/2177/16-к. URL: http://www.reyestr.court.gov.ua/Review/57690527 